\title{
ANALISIS KINERJA KOPERASI PRODUSEN TEMPE TAHU INDONESIA (KOPTI) DI KABUPATEN BOGOR PROVINSI JAWA BARAT DENGAN METODE BALANCED SCORECARD
}

\author{
E. Antoni ${ }^{1}$, A. $\operatorname{Arsyad}^{1 \mathrm{a}}, \mathrm{H} . \mathrm{Miftah}^{1}$ \\ ${ }^{1}$ Jurusan Agribisnis, Fakultas Pertanian, Universitas Djuanda Bogor \\ Jalan Tol Ciawi No. 1 Kotak Pos 35 Bogor 16720 \\ ${ }^{a}$ Korespondensi: Apendi Arsyad, Telp: 08129347542, Email:apendi.arsyad@unida.ac.id
}

\begin{abstract}
ABSTRAK
Dalam kehidupan sehari-hari, persaingan lingkungan bisnis dalam bidang pertanian khususnya koperasi, perencanaan strategis yang tepat merupakan suatu faktor yang harus diperhatikan untuk mencapai target yang diinginkan. Pengukuran kinerja tersebut dilakukan untuk mengevaluasi pengukuran kinerja secara menyeluruh, dengan menggunakan pendekatan Balanced Scorecard. Balanced Scorecard merupakan alat ukur kinerja yang menyeimbangkan empat perspektif, yaitu perspektif pelanggan, perspektif keuangan, perspektif proses bisnis intenal serta perspektif pembelajaran dan pertumbuhan. Studi analisis kinerja KOPTI Kabupaten Bogor ini menggunakan metode Balanced Scorecard, yang dinilai secara keseluruhan mencapai hasil yang cukup baik, dengan total capaian keseluruhan dari keempat perspektif Balanced Scorecard tersebut adalah sebesar 72,90\%. Hal ini berarti bahwa kinerja KOPTI Kabupaten Bogor pada tahun 2012 tergolong dalam kategori Sangat Sehat (A) karena total skor berada pada selang $65<$ Total Skor $<80$. Total skor pada perspektif pelanggan sebesar $8,58 \%$, total perspektif keuangan sebesar $17,88 \%$, total perspektif proses bisnis internal sebesar $17,60 \%$, dan total perspektif pembelajaran dan pertumbuhan sebesar $28,84 \%$.
\end{abstract}

Kata kunci: Pengukuran kinerja, Balanced Scorecard, KOPTI Kabupaten Bogor 
PENDAHULUAN

Jumlah koperasi di Indonesia mengalami peningkatan dari tahun $2006 \mathrm{ke}$ tahun 2012. Kenaikan tersebut terjadi secara kontinu dari 2006 ke 2012. Namun terdapat juga peningkatan koperasi yang tidak aktif. Perbandingan antara jumlah koperasi aktif dan tidak aktif dapat dilihat pada Tabel 1. Jumlah koperasi yang tidak aktif dari tahun ke tahun semakin meningkat walaupun jumlah koperasi aktif juga semakin meningkat sehingga diperlukan langkah untuk menurunkan jumlah koperasi yang tidak aktif.

Tabel. 1. Jumlah Koperasi Aktif dan Tidak Aktif Tahun 2006-2012

\begin{tabular}{cccc}
\hline No & Tahun & Koperasi Aktif (unit) & Koperasi Tidak Aktif (unit) \\
\hline 1 & 2006 & 98.944 & 42.382 \\
2 & 2007 & 104.999 & 44.794 \\
3 & 2008 & 108.930 & 46.034 \\
4 & 2009 & 120.473 & 49.938 \\
5 & 2010 & 124.855 & 52.627 \\
6 & 2011 & 133.666 & 54.515 \\
7 & 2012 & 139.321 & 54.974 \\
\hline
\end{tabular}

Sumber : Kementrian Negara Koperasi dan UMKM, 2012

Ketepatan strategi yang akan dilakukan pada koperasi sangat berpengaruh terhadap keberhasilan koperasi nantinya. Ketepatan atas penentuan strategi dapat diukur dengan pengukuran kinerja baik dalam sisi organisasi mapun individu.Berdasarkan uraian diatas, maka dapat dirumuskan beberapa masalah, antara lain : Bagaimana keragaan dan kondisi lingkungan usaha KOPTI Kabupaten Bogor saat ini? Bagaimana target yang dilakukan KOPTI

\section{BAHAN DAN METODE}

\section{Koperasi}

Pengertian koperasi dijelaskan dalam UU No. 17 Tahun 2012, koperasi didefinisikan sebagai "Badan hukum yang didirikan oleh orang perseorangan atau badan hukum koperasi, dengan pemisahan kekayaan para anggotanya sebagai modal untuk menjalankan usaha yang memenuhi aspirasi dan kebutuhan bersama di bidang ekonomi, sosial, dan budaya sesuai dengan nilai dan prinsip koperasi”.

\section{Konsep Strategi}

Pada umumnya strategi adalah proses penentuan rencana kerja para pemimpin puncak yang berfokus pada tujuan jangka panjang organisasi, disertai penyusunan
Kabupaten Bogor saat ini dan Bagaimana kinerja KOPTI Kabupaten Bogor yang diukur dengan metode Balanced Scorecard?

Penelitian ini bertujuan untuk Memberikan gambaran keragaan dan kondisi serta potensi lingkungan usaha KOPTI Kabupaten Bogor, menentukan target yang telah ditetapkan KOPTI Kabupaten Bogor saat ini, dan menganalisis kinerja KOPTI Kabupaten Bogor dengan metode Balanced Scorecard.

suatu cara atau upaya bagaimana agar tujuan tersebut dapat dicapai.

\section{Konsep Balanced Scorecard}

Menurut Robert S. Kaplan dan David P. Norton (2000) menjelaskan Balanced Scorecard (BSC) yaitu suatu sistem manajemen penilaian dan pengendalian yang secara cepat, tepat dan komprehensif dan memberikan pemahaman kepada manajer tentang kinerja bisnis. BSC membagi strategi dan pengukurannya ke dalam empat perspektif, yaitu pelanggan, keuangan, proses bisnis internal, serta pembelajaran dan pertumbuhan

\section{Kerangka Pemikiran}

Tujuan dan ukuran Balanced scorecard diturunkan dari visi dan strategi. 
Tujuan dan ukuran memandang kinerja dari empat perspektif (keuangan, anggota/ pelanggan, proses bisnis internal serta pembelajaran dan pertumbuhan). Dilakukannya pengukuran kinerja guna untuk memperoleh kinerja yang baik di masa yang akan datang. Alur kerangka pemikiran operasional pada penelitian ini dapat dilihat pada Lampiran 1.

\section{Lokasi dan Waktu Penelitian}

Penelitian ini dilakukan di Koperasi Produsen Tempe Tahu Indonesia (KOPTI), J1. Raya Cilendek No 27 Kab. Bogor, Jawa Barat. Pemilihan lokasi ini dilakukan secara sengaja (purposive). Waktu penelitian dilaksanakan pada tanggal 3 Juni sampai dengan 3 Juli 2013.

\section{Jenis dan Sumber Data}

Jenis Jenis data yang digunakan dalam penelitian ini mencakup data primer dan data sekunder. Sumber data primer diperoleh melalui wawancara langsung terhadap responden di lokasi penelitian dengan menggunakan daftar pertanyaan (kuesioner) yang telah disediakan. Sedangkan data skunder diperoleh dari data resmi yang diterbitkan Kementerian Koperasi dan UMKM RI, jurnal ilmiah, buku, penelitian terdahulu dan literaturliteratur pendukung lainnya untuk mengumpulkan data yang dibutuhkan dalam penelitian ini seperti data perkembangan dan daftar hadir anggota, faktor produksi kedelai, iklim daerah penelitian dan geografi wilayah serta data penunjang lainnya yang relevan untuk kebutuhan penelitian ini.

\section{Metode Pengambilan Sampel}

Metode pengambilan sampel yang digunakan dalam penelitian ini adalah nonprobability sampling dengan teknik convenience sampling. Jumlah sampel yang digunakan adalah 60 orang. Penentuan jumlah sampel tersebut berdasarkan pendapat Supranto (2011), bahwa jumlah minimal sampel adalah 30 responden, 30 anggota dan 30 karyawan karena secara empiris jumlah tersebut memiliki distribusi peluang rata-rata dan distribusi normal.

Menurut sekaran (2000), ukuran sampel lebih besar dari 30 dan kurang dari 500 telah mencukupi untuk digunakan dalam penelitian, dengan catatan bahwa sampel tersebut cukup mewakili populasi dengan pertimbangan biaya dan waktu.

\section{Metode Analisis Data}

Metode yang digunakan untuk menganalisis data dalam penelitian ini adalah analisis deskriptif, pengukuran kinerja dengan Balanced Scorecard yaitu dengan nilai pembobotan (dengan matriks perbandingan berpasangan), pengukuran kinerja dan kepuasan anggota pada empat perspektif, yaitu Perspektif Pelanggan (dengan Customer Statisfaction Index/CSI), Perspektif Keuangan (dengan menentukan Rasio Lukuiditas, Rasio Solvabilitas, Rasio Rentabilitas dan Rasio Aktivitas), Perspektif Proses Bisnis Internal dan Perspektif Pembelajaran dan Pertumbuhan (dengan Customer Statisfaction Index/CSI).

\section{HASIL DAN PEMBAHASAN}

\section{Penentuan Ukuran Kinerja}

Pada penentuan ukuran kinerja KOPTI Kabupaten Bogor berdasarkan visi dan misi yang telah dijabarkan pada setiap perspektif tersebut. Ukuran kinerja KOPTI Kabupaten Bogor adalah sebagai berikut:

\section{Perspektif Pelanggan}

Pada pespektif pelanggan, sasaran strategis yang ingin dicapai yaitu kepuasan pelanggan serta tingkat kehadiran anggota pada saat RAT. Untuk mengukur kepuasan anggota, melibatkan 30 orang anggota, sedangkan untuk kehadiran anggota dalam RAT adalah persentase kehadiran anggota pada saat RAT.

\section{Perspektif Keuangan}

Pada Perspektif keuangan, sasaran startegis yang ingin dicapai yaitu peningkatan rasio keuangan, penerimaan usaha serta nilai SHU.

\section{Perspektif Proses Bisnis Internal}

Pada perspektif proses bisnis internal, sasaran strategis yang ingin dicapai yaitu 
pengembangan usaha koperasi serta peningkatan aktivitas pada setiap unit usaha koperasi, dan

\section{Perspektif Pembelajaran dan Pertumbuhan}

Pada pesrpektif pembelajaran dan pertumbuhan, sasaran strategis yang ingin dicapai yaitu adanya evaluasi kinerja secara rutin terhadap karyawan, peningkatan kepuasan karyawan serta peningkatan pembinaan terhadap anggota.

\section{Penentuan Target pada Ukuran Kinerja}

Penentuan target dalam pengukuran kinerja diperlukan untuk mengukur apakah KOPTI Kabupaten Bogor telah berhasil dalam menjalankan kegiatannya dilihat dari pencapaian terhadap target yang telah ditetapkan. Penetapan target ini menjadi tolak ukur KOPTI Kabupaten Bogor dalam menacapai sasaran strategisnya. Penetapan target untuk KOPTI Kabupaten Bogor pada setiap perspektif dapat dijelaskan sebagai berikut :

\section{Perspektif Pelanggan}

Sasaran strategis untuk perspektif pelanggan di KOPTI Kabupaten Bogor adalah kepuasan anggota serta partisipasi dan kontribusi anggota. Pada sasaran kepuasan anggota ukuran kinerja dilihat dari indeks kepuasan angota dengan presentase target terhadap kepuasan anggota yang ditetapkan sebesar 100 persen. Pada sasaran strategis kehadiran anggota pada saat RAT, ukuran kinerja untuk melihat hal tersebut melalui tingkat kehadiran anggota pada saat RAT dengan target yang ditetapkan sebesar 100 persen di tahun 2012.

\section{Perspektif Keuangan}

Sasaran strategis untuk perspektif keuangan di KOPTI Kabupaten Bogor terdiri atas tiga sasaran strategis. Sasaran strategis yang pertama adalah rasio keuangan yang terdiri atas rasio likuiditas dengan penetapan target sebesar 600 persen, rasio solvabilitas dengan penetapan target maksimal 250 persen dan rasio rentabilitas dengan penetapan target minimal 1 persen serta rasio aktivitas dengan target 150 persen. Sasaran strategis yang kedua adalah penerimaan usaha koperasi dengan ukuran kinerja yang dilihat dari penerimaan usaha KOPTI Kabupaten Bogor selama tahun 2012 dengan penetapan target sebesar Rp. 38.000.000.000. Sasaran strategis yang ketiga adalah Sisa hasil Usaha (SHU) dengan ukuran kinerja yang dilihat melalui SHU KOPTI Kabupaten Bogor selama tahun 2012 dengan penetapan target sebesar Rp. 350.000.000.

\section{Perspektif Proses Bisnis Internal}

Sasaran strategis pada perspektif proses bisnsi internal terdiri dari pengembangan usaha koperasi serta peningkatan aktivitas pada setiap unit usaha di koperasi. Sasaran strategis pengembangan usaha koperasi memiliki ukuran kinerja yang dilihat dari macam unit usaha yang dijalankan koperasi dengan target jumlah unit usaha sebanyak 4 unit usaha yang terdiri atas unit usaha peningkatan produksi kedelai, peningkatan unit simpan pinjam, peningkatan penyerapan bahan pembantu, dan pengembangan usaha pengadaan alat produksi.

\section{Perspektif Pembelajaran dan Pertumbuhan}

Sasaran strategis pada perspektif pembelajaran dan pertumbuhan terdiri atas adanya evaluasi kinerja karyawan secara rutin, kepuasan karyawan serta pembinaan karyawan. Ukuran kinerja dari sasaran strategis adanya evaluasi kinerja karyawan secara rutin adalah jumlah rapat evaluasi yang diadakan dalam satu tahun dengan penetapan target sebanyak 12 kali rapat evaluasi yang diadakan setiap bulannya dalam satu tahun. Ukuran kinerja untuk kepuasan karyawan adalah indeks kepuasan karyawan dengan penetapan target sebesar 100 persen. Sedangkan untuk ukuran kinerja pada sasaran strategis pembinaan karyawan adalah jumlah pertemuan pihak koperasi dengan karyawan dengan penetapan target sebanyak 12 pertemuan dalam satu tahun. 
Analisis Kinerja KOPTI Kab. Bogor dengan Metode Balanced Scorecard

Kegiatan pengukuran pada analisis kinerja di KOPTI Kabupaten Bogor dengan menggunakan Blanced Scorecard dilakukan dengan membandingkan target dengan realisasi kinerja pada tahun 2012 sehingga didapatkan nilai pencapaian yang akan diperhitungkan dengan bobotnya masing-masing.

\section{Analisis Kinerja Perspektif Pelanggan}

Pada perspektif pelanggan yang menjadi fokus perhatian yaitu bagaimana perusahaan mempertahankan pelanggan dan meningkatkan jumlah pelanggan yang baru. Tolak ukur pada perspektif pelanggan yaitu peningkatan kepuasan anggota dan kehadiran anggota pada saat RAT.

Peningkatan kepuasan anggota diukur melalui indeks kepuasan anggota dengan melibatkan 30 responden anggota KOPTI Kabupaten Bogor dari 1.373 anggota dengan menggunakan analisis Customer Statisfaction Index (CSI) Analsis yang digunakan pada pengukuran kepuasan anggota adalah Customer Statisfaction Index (CSI), hasil tersebut dapat dilihat pada Lampiran 2.

Sasaran strategis pada perspektif pelanggan selain kepuasan anggota adalah kehadiran anggota pada saat RAT dengan ukuran hasil tingkat kehadiran anggota pada saat RAT. Kegiatan RAT merupakan kegiatan yang dilakukan setiap akhir tahun oleh KOPTI Kabupaten Bogor. Pelaksanaan RAT di tahun 2012 pada tanggal 11 Januari 2013 dan merupakan RAT yang ke-30. Persentase kehadiran anggota pada saat RAT, terlihat bahwa anggota akti di koperasi selalu hadir pada saat RAT, penetapan target untuk kehadiran anggota pada saat RAT adalah 100\%. Hal ini berarti di tahun 2012 KOPTI Kabupaten Bogor telah berhasil mencapai targetnya.

\section{Analisis Kinerja Perspektif Keuangan}

Penilaian kinerja pada perspektif keuangan dilakukan terhadap tiga sasaran strategis yang telah ditetapkan yaitu rasio keuangan dengan ukuran hasil rasio likuiditas, rasio solvabilitas serta rasio rentabilitas dan rasio aktivitas, penerimaan usaha koperasi dengan ukuran hasil total penerimaan usaha koperasi dan SHU koperasi dengan ukuran hasil total perolehan SHU koperasi. Perkembangan kondisi rasio keuangan di KOPTI Kabupaten Bogor dapat dilihat pada Lampiran 3.

Sasaran strategis yang kedua pada perspektif keuangan adalah pendapatan koperasi. Ukuran hasil dari sasaran strategis ini adalah total pendapatan koperasi. Pendapatan utama dari KOPTI Kabupaten Bogor didapat dari penjualan kedelai. Selain itu, pendapatan KOPTI Kabupaten Bogor juga didapat dari penjualan bahan pembantu, penjualan peralatan produksi, sewa tempat, angkutan barang/sewa angkutan serta pendapatan dari bank jika ada.

Pada tahun 2012, penjualan didapat dari penjualan kedelai serta penjualan bahan pembantu. Nilai pendapatan yang didapat koperasi di tahun ini sebesar Rp. 36.939.446.960 dengan penetapan target sebesar Rp. 38.000.000.000. Perkembangan pendapatan KOPTI kabupaten Bogor tahun 2010-2012 dapat dilihat pada Lampiran 4.

Sasaran strategis ketiga pada perspektif keuangan adalah perolehan SHU koperasi dengan ukuran kecil hasil nilai perolehan SHU koperasi di tahun 2012. Nilai SHU ini merupakan nilai yang didapat dari pendapatan bersih yang telah dikurangi biaya-biaya yang nantinya akan dibagikan secara merata kepada seluruh anggota aktif di KOPTI Kabupaten Bogor. Perkembangan nilai SHU di KOPTI kabupaten Bogor sejak tahun 2010 hingga tahun 2012 dapat dilihat pada Lampiran 5.

\section{Analisis Kinerja Proses Bisnis Internal}

Sasaran strategis pertama yang ingin dicapai yaitu pengembangan usaha koperasi. Unit usaha yang dirancang terdiri atas 4 (empat) unit usaha untuk 
dikembangkan dan menjadi target hingga tahun 2017. Namun dari 4 unit usaha tersebut, hanya terlaksana 3 unit usaha yang dapat dikembangkan.

Unit usaha peningkatan penyerapan bahan pembantu juga memberikan kontribusi dalam pendapatan koperasi. Keberadaan koperasi yang unik dimana anggota menjadi pemilik sekaligus pelanggan, akan menyebabkan keberhasilan koperasi berada pada sejauh mana anggota aktif dalam kegiatan usaha di koperasi. Kontribusi anggota dalam menyerap bahan pembantu akan berdampak pada peningkatan penjualan bahan pembantu kedelai. Perkembangan penyerapan bahan pembantu oleh anggota dapat dilihat pada Lampiran 6.

Target koperasi yang ditetapkan untuk penyerapan bahan pembantu di tahun 2012 sebesar $6.000 \mathrm{Kg}$. Penyerapan bahan pembantu di tahun 2012 sebesar 5.207 Kg yang berarti KOPTI Kabupaten Bogor terjadi penurunan sebesar $-20,38 \%$

Unit lainnya yaitu unit simpan pinjam. Unit simpan pinjam ini bertujuan untuk membantu anggota dalam hal pembiayaan. Sesuai dengan rencana kerja dalam rangka meningkatkan pelayanan dan pemenuhan kebutuhan anggota, maka unit simpan pinjam didirikan untuk membantu anggota koperasi dimana anggota bisa melakukan pinjaman dengan bunga sebesar 1-2 \% perbulan. Perkembangan modal unit simpan pinjam dapat dilihat Lampiran 7.

\section{Analisis Kinerja Perspektif Pembelajaran dan Pertumbuhan}

Sasaran strategis yang ditetapkan pada perspektif pembelajaran dan pertumbuhan di KOPTI Kabupaten Bogor terdiri atas tiga sasaran strategis yaitu adanya evaluasi kinerja secara rutin terhadap karyawan dengan ukuran kinerja jumlah rapat evaluasi di tahun 2012, peningkatan kepuasan karyawan dengan ukuran kinerja indeks kepuasan karyawan serta peningkatan pembinaan anggota dengan ukuran kinerja jumlah pertemuan dengan anggota.
Sasaran strategis pertama adanya evaluasi kinerja terhadap karyawan secara rutin berguna untuk meningkatkan kualitas dari kinerja karyawan. Target yang ditetapkan untuk pelaksanaan rapat evaluasi minimal 1 bulan sekali. Analisis yang digunakan pada pengukuran kepuasan karyawan adalah Customer Statisfaction Index (CSI). hasil tersebut dapat dilihat Lampiran 8.

\section{KESIMPULAN DAN IMPLIKASI KEBIJAKAN Kesimpulan}

Dari hasil uraian dalam penelitian ini dapat disimpulkan sebagai berikut :

1. OPTI Kabupaten bogor telah memiliki alat-alat struktur dan perangkat organisasi yang berfungsi cukup baik, yaitu RAT yang diselenggarakan secara rutin, adanya pengurus yang bekerja dengan manajemen usaha dengan baik, potensi anggota yang dapat dikembangkan dan ditingkatkan baik dari jumlah maupun partisipasinya, serta lingkungan organisasi yang strategis untuk pengembangan usaha. Sedangkan dari segi usaha, KOPTI Kabupaten Bogor memiliki potensi yang bisa dikembangkan seperti pengembangan usaha produksi, pengembangan usaha simpan pinjam, pengembangan usaha alat produksi, dan pengembangan usaha alat pembantu

2. Pada target masing-masing perspektif yang ditetapkan KOPTI Kabupaten Bogor. Ada beberapa perspektif yang belum mencapai target yang diinginkan, terutama pada perspektif pelanggan. Pada pespektif ini indeks kepuasan anggota hanya mencapai $78,60 \%$ dari $100 \%$ target yang ditentukan, tingkat kehadiran anggota pada saat RAT hanya mencapai 3,64\% dari $100 \%$ target yang ditentukan dan pada perkembangan SHU hanya mencapai $46,03 \%$ dari $100 \%$ target yang dinginkan. Serta pada pespektif proses bisnis internal, masih ada unit 
usaha yang tidak berjalan yaitu pengadaan alat produksi, dan

3. Kinerja KOPTI Kabupaten Bogor secara keseluruhan mencapai hasil yang cukup baik, dimana total keseluruhan dari keempat perspektif tersebut sebesar $72,90 \%$, hal ini berarti bahwa kinerja KOPTI Kabupaten Bogor pada tahun 2012 tergolong kedalam kategori sangat sehat (A). Karena total skor berada pada selang $65<$ Total skor $<80$. Total skor pada perspektif pelanggan sebesar $8,58 \%$, total perspektif keuangan sebesar $17,88 \%$, total perspektif proses bisnis internal sebesar $17,60 \%$ dan total perspektif pembelajaran dan pertumbuhan sebesar 28,84\%. Meskipun kinerja secara keseluruhan dinilai cukup bai, namun adanya ketidakoptimalan dan ketidak berhasilan pencapaian target yang telah ditentukan.

\section{Implikasi Kebijakan}

Berdasarkan hasil analisis kinerja KOPTI Kabupaten Bogor, maka saran yang dapat direkomendasikan adalah sebagai berikut :

1. Pengembangan unit usaha simpan pinjam, sebaiknya tidak lagi dilakukan pemberian pinjaman berdasarkan kepercayaan tetapi berdasarkan karakter peminjam untuk mencegah terjadinya kredit macet serta mulai mempertimbangkan pemberian insentif bagi anggota yang membayar kredit secara tepat waktu, seperti pemberian hadiah atau potongan sisa angsuran, hal ini diharapkan dapat memacu anggota untuk membayar kredit tetap awktu.

2. KOPTI Kabupaten Bogor harus tetap mempertahankan tindakan manajerial koperasi yang sudah menghasilkan pencapaian kinerja yang cukup baik berdasarkan BSC agar target yang di tetapkan bisa tercapai. Pada pengembangan unit usaha, masih ada satu unit lagi yang tidak berjalan dan harus dikembangkan lagi dan sebaiknya KOPTI Kabupaten Bogor memberikan kemudahan akses bagi anggota, dan

3. Penerapan Balanced Scorecard yang telah dilakukan KOPTI dengan dengan menganalisis kinerja dari seluruh perspektif, KOPTI Kabupaten Bogor tidak hanya melakukan mengukur pada perspektif keuangan saja, tetapi KOPTI Kabupaten Bogor harus menerapkan mengukur secara keseluruhan yaitu perspektif pelanggan, perspektif proses bisnis internal serta perspektif pembelajaran dan pertumbuhan, guna untuk mencapai target yang diinginkan.

\section{DAFTAR PUSTAKA}

David, FR. 2009. Manajemen Strategis: Konsep (terjemahan). Jakarta: Salemba Empat.

Hunger, J. David dan Thomas L. Wheelen. 2003. Manajemen Strategis (terjemahan). Yogyakarta.

Kementerian Negara Koperasi dan UMKM 2012. Rekapitulasi Data Koperasi Tahun 2006-20012. http://www.depkop.go.id [diakses tanggal 7 Maret 2013].

Koperasi Produsen Tempe Tahu Indonesia. 2012. Laporan Tahunan Pengurus Tahun 2012. Bogor. Primer Koperasi Produsen Tempe Tahu Indonesia.

Pearce, JA dan Robinson. 1997. Manajemen Strategi: Formulasi, Implementasi dan Pengendalian. Jakarta: Bina Rupa Aksara

Sekaran U. 2000. Research Method for Bussiness A Skill Building Appoach Edisi Tiga. Singapore: John Willey dan Sons.

Supranto J. 2011. Pengukuran Tingkat Kepuasan Pelanggan. Jakarta. PT. Rineka Cipta.

UU Republik Indonesia. Nomor 17 Tahun 2012 Tentang Perkoperasian. www.hukumonline.com [diakses tanggal 14 Mei 2013]. 